\title{
PENGARUH MOL ( Mikroorganisme Lokal) TERHADAP PENGGEMUKAN SAPI POTONG SEBAGAI UPAYA PENINGKATAN PENDAPATAN PETERNAK
}

\section{Disusun Oleh:}

\author{
Wenny Mamilianti \\ Dosen Fakultas Pertanian Universitas Yudharta Pasuruan \\ Adip Yusroni \\ Mahasiswa Agribisnis Universitas Yudharta Pasuruan
}

\begin{abstract}
ABSTRAK
Salah satu masalah yang umum dihadapi oleh peternak tradisional adalah rendahnya mutu pakan dengan kandungan serat kasar yang tinggi, berupa jerami, rumput lapangan dan berbagai jenis hijauan lainnya. Untuk meningkatkan mutu pakan perlu dilakukan proses fermentasi dengan menggunakan mikroorganisme (MOL). Bahan untuk membuat MOL bisa diperoleh dari lingkungan sekitar, namun yang telah terbukti menambah pendapatan peternak belum bisa diketahui. Tujuan dalam penelitian ini : (1) Mengetahui MOL yang mampu memberikan penambahan berat badan harian ternak sapi. (2) Mengetahui pengaruh fermentasi pakan terhadap peningkatan kadar protein dan penurunan kadar serat kasar pakan. (3) Menganalisis kelayakan usaha penggemukan ternak sapi. Penelitian ini menggunakan Rancangan percobaan yaitu Rancangan Acak Kelompok Faktor Tunggal yaitu penambahan MOL pada jerami sebanyak 3 level perlakuan. Hasil Penelitian menunjukkan bahwa Perlakuan Jerami+MOL Buah memberikan Pertambahan Berat Badan Harian PBBH ternak terbaik yaitu sebesar 0,96 (kg/ekor/hr). Hasil Fermentasi terhadap jerami dengan perlakuan MOL yang menunjukkan hasil terbaik adalah fermentasi dengan penambahan MOL Buah yaitu kandungan protein kasar 9,12 dan kandungan serat kasar 24,34 Usaha penggemukan sapi potong dengan pemberian pakan hasil fermentasi Jerami+Mol Buah layak diusahakan karena mampu memberikan nilai keuntungan.
\end{abstract}

Kata Kunci: MOL, Penggemukan, Sapi Potong, Layak usaha

\section{PENDAHULUAN}

Salah satu masalah yang umum dihadapi oleh peternak tradisional adalah rendahnya mutu pakan dengan kandungan serat kasar yang tinggi, berupa jerami, rumput lapangan dan berbagai jenis hijauan lainnya. Jenis pakan ternak tersebut sulit dicerna dan tidak dapat memberikan zat-zat nutrisi yang berimbang untuk mendukung produktivitas yang optimal, perlu adanya teknologi yang bertujuan untuk meningkatkan kualitas ternak yang pada akhirnya akan meningkatkan kualitas daging ternak. Pola pemberian pakan jerami fermentasi dan dedak halus memberikan PBBH yang optimal.
Proses fermentasi dapat meningkatkan protein kasar hingga mencapai 72,12 dan menurunkan kandungan serat kasar sampai 25,68 persen.

Untuk meningkatkan mutu pakan perlu dilakukan proses fermentasi dengan menggunakan mikroorganisme. Mikroorganisme ini berguna untuk mempercepat proses pemecahan serat jerami padi, sehingga mudah dicerna oleh ternak. Menurut Januardani (2008) MOL (Mikro Organisme Lokal) adalah kumpulan dari beberapa mikro organisme yang bisa diternakkan dan berfungsi untuk "starter" dalam pembuatan kompos, pupuk cair ataupun pakan ternak. Didalam peternakan penambahan MOL kedalam konsentrat 
ternak berperan pada proses fermentasi dalam mencerna bahan-bahan makanan basal ( pencernaan fermentatif) yang pada akhirnya akan meningkatkan kualitas daging.

Bahan untuk membuat MOL bisa diperoleh dari lingkungan sekitar, namun yang telah terbukti mampu meningkatkan kualitas daging ternak dan sekaligus menambah pendapatan peternak belum bisa diketahui. Oleh karena itu penelitian ini penting untuk dilakukan.

\section{PERUMUSAN MASALAH}

perumusan masalah dalam penelitian ini adalah :

a. Mikroorganisme lokal manakah yang mampu memberikan penambahan berat badan harian ternak sapi?

b. Apakah konsentrat hasil fermentasi dapat meningkatkan kadar protein dan menurunkan kadar serat kasar konsentrat?

c. Apakah usaha penggemukan ternak sapi layak diusahakan secara finansial ?

\section{TUJUAN}

Tujuan dalam penelitian ini:

a. Mengetahui mikroorganisme lokal (MOL) yang mampu memberikan penambahan berat badan harian ternak sapi.

b. Mengetahui pengaruh fermentasi pakan peningkatan kadar protein dan penurunan kadar serat kasar pakan?

c. Menganalisis kelayakan usaha penggemukan ternak sapi

\section{TINJAUAN PUSTAKA}

\section{Konsentrat}

Pakan penguat (konsentrat) adalah pakan yang mengandung serat kasar relatif rendah dan mudah dicerna. Bahan pakan penguat ini meliputi bahan pakan yang berasal dari biji-bijian seperti jagung giling, menir, dedak, katul, bungkil kelapa, tetes, dan berbagai umbi. Fungsi pakan penguat adalah meningkatkan dan memperkaya nilai gizi pada bahan pakan lain yang nilai gizinya rendah. (Sugeng, 1998). Menurut Darmono (1999) konsentrat adalah bahan pakan yang mengandung serat kasar kurang dari 18\%, berasal dari biji- bijian, hasil produk ikutan pertanian atau dari pabrik dan umbiumbian. Bekatul dalam susunannya mendekati analisis dedak halus, akan tetapi lebih sedikit mengandung selaput putih dan bahan kulit, di dalam bekatul juga tercampur pecahan halus dari menir. Kandungan nutrien dari bekatul adalah 15\% air, 14,5\% PK, 48,7\% bahan ekstrak tanpa nitrogen (BETN), 7,4\% SK, 7,4\% LK dan 7,0 \% abu, kadar protein dapat dicerna $10,8 \%$ dan Martabat pati (MP) = 70 (Lubis, 1992). Menurut Santosa (1995) bekatul mengandung $85 \% \mathrm{BK}, 14 \% \mathrm{PK}, 87,6 \%$ TDN, 0,1\% kalsium (Ca) dan 0,8\% phospor (P). Ampas tahu adalah ampas yang diperoleh dari pembuatan tahu yang diberikan kepada ternak besar dan kecil. Ampas tahu dalam keadaan segar mengandung lebih dari $80 \%$ air. Kandungan nutrien dari ampas tahu adalah 84\% air, 5\% PK, 5,8\% (bahan ekstrak tanpa nitrogen) BETN, 3,2 \% SK, 1,2\% LK, dan 0,8\% abu. Ampas tahu yang sudah dikeringkan masih mengandung kira-kira 16\% air, dengan kadar protein dapat dicerna (Prdd) 22,3\% dan nilai $\mathrm{MP}=629$ (Lubis, 1992). Menurut Siregar (1994) ampas tahu mengandung 23\% BK, 23,7\% PK,23,6\% SK dan $79 \%$ TDN. Ketela pohon (Manihot utilissima) mempunyai umbi dengan kadar tepung yang sangat tinggi. Umbi ketela pohon yang masih segar tidak dianjurkan diberikan pada ternak 
secara rutin, karena mengandung racun sianida yang sangat berbahaya (Lubis, 1992). Menurut Siregar (2008), kandungan nutrisi ketela pohon adalah 32,3\% BK, 3,3\% PK, 4,2\% SK, 81,8\% TDN.

\section{Pertumbuhan}

Pertumbuhan

adalah pertambahan berat badan atau ukuran tubuh sesuai dengan umur, sedangkan perkembangan adalah berhubungan dengan adanya perubahan ukuran serta fungsi dari berbagai bagian tubuh semenjak embrio sampai menjadi dewasa. Proses pertumbuhan pada ternak sapi dimulai sejak awal terjadinya pembuahan sampai dengan pedet itu lahir, dilanjutkan hingga sapi menjadi dewasa (Sugeng, 1998). Menurut Anggorodi (1994) pertumbuhan biasanya dimulai perlahan-lahan kemudian mulai berlangsung lebih cepat dan akhirnya perlahan-lahan lagi atau sama sekali berhenti sehingga membentuk kurva pertumbuhan yang berbentuk sigmoid. Menurut Siregar (2008) pertumbuhan yang cepat terjadi pada periode lahir hingga usia penyapihan dan pubertas, namun setelah usia pubertas hingga usia dewasa, laju pertumbuhan mulai menurun dan akan terus menurun hingga usia dewasa. Pada usia dewasa, pertumbuhan sapi berhenti. Sejak sapi dilahirkan sampai dengan usia pubertas (sekitar umur 8-10 bulan) merupakan fase hidup sapi yang laju pertumbuhannya10 sangat cepat.

Pertambahan bobot badan sapi ditentukan oleh berbagai faktor, terutama jenis sapi, jenis kelamin, umur, ransum, dan teknik pengelolaannya.

\section{Kebutuhan Pakan}

Kebutuhan ternak akan zat gizi terdiri atas kebutuhan hidup pokok dan produksinya. Zat-zat pakan dalam ransum hendaknya tersedia dalam jumlah yang cukup dan seimbang sebab keseimbangan zat-zat pakan dalam ransum sangat berpengaruh terhadap daya cerna (Tillman et al., 1991). Kemampuan ternak ruminansia dalam mengkonsumsi ransum dipengaruhi oleh beberapa faktor yaitu : 1) faktor ternak itu sendiri yang meliputi besar tubuh atau bobot badan, potensi genetik, status fisiologi, tingkat produksi dan kesehatan ternak; 2) faktor ransum yang diberikan, meliputi bentuk dan sifat, komposisi zat-zat gizi, frekwensi pemberian, keseimbangan zat-zat gizi serta kandungan bahan toksik dan anti nutrisi; dan 3) faktor lain yang meliputi suhu dan kelembaban udara, curah hujan, lama siang atau malam hari serta keadaan ruangan kandang dan tempat ransum. Konversi pakan dipengaruhi oleh ketersediaan zat-zat gizi dalam ransum dan kesehatan ternak, semakin tinggi nilai konversi pakan berarti pakan yang digunakan untuk menaikkan bobot badan persatuan berat semakin banyak atau efisiensi pakan rendah (Siregar, 1994).

\section{Implementasi MOL (Mikroorganisme Lokal) Dalam Pembuatan Pakan Ternak}

Menurut Direktorat Pengelolaan Lahan (2007) Mikro Organisme Lokal (MOL) adalah larutan yang terbentuk dari campuran bahan-bahan alami yang disukai tanaman sebagai media hidup dan berkembangnya mikroorganisme. MOL bermanfaat untuk mempercepat proses penghancuran bahan-bahan organik. Menurut Januardani (2008) dalam blognya, MOL adalah kumpulan dari beberapa mikro organisme yang bisa diternakkan dan berfungsi untuk "starter" dalam pembuatan kompos organik. Namun, selain digunakan untuk starter MOL juga dapat digunakan sebagai pestsida nabati. 
Sedangkan berdasarkan SMPT Harapan Rakyat (2008) MOL yang digunakan sebagai pestisida nabati biasanya adalah MOL yang terbuat dari urine hewan dan kotoran hewan. Secara lebih lengkap MOL hasil fermentasi pada dasarnya dapat digunakan sebagai kebutuhan yang lain, yaitu seperti : pupuk cair, stater dalam pembuatan kompos, campuran minuman atau pakan ternak, campuran pakan ikan, pestisida nabati, penguras wc, penghilang bau pada kotoran ternak, zat perangsang tumbuh.

Berdasarkan blog yang ditulis oleh Rimbulam (2008) tedapat beberapa bahan utama dalam pembuatan MOL. Bahan-bahan utama dalam pembuatan MOL tersebut terdiri dari tiga jenis komponen dasar, yaitu :

1. Karbohidrat : Komponen karbohidrat dapat diperoleh dari air cucian beras (Tajin), nasi bekas (basi) ,singkong, kentang , gandum, tapai dan bahan-bahan lainnya.

2. Glukosa : Komponen glukosa dapat diperoleh dari gula merah yang diencerkan dengan air (dihancurkan sampai halus), cairan gula pasir, gula batu dicairkan, air gula , air kelapa.

3. Sumber Bakteri : Komponen bakteri dapat diperoleh dari keong, kulit buah-buahan (misalnya tomat, pepaya, dll), sayuran hijauan (misalnya Kol, Caisin, Petsay, dll), air kencing hewan, atau apapun yang mengandung sumber bakteri lainnya.

\section{METODE PENELITIAN}

\section{Tempat Penelitian}

Penelitian dilakukan di dua tempat yaitu (1) di laboratorium Pangan Universitas Yudharta Pasuruan untuk uji protein dan uji kadar serat daging, (2) di kandang seorang peternak dimana ternak sapinya akan digunakan sampel dalam penelitian.

\section{Rancangan Percobaan}

Penelitian ini merupakan penelitian eksperimental dengan satu variabel bebas yaitu penambahan macam MOL terhadap jerami dan tiga variabel tergantung yaitu penambahan kadar protein, kandungan serat pada pakan, pertambahan berat badan harian ternak. Rancangan percobaan menggunakan Rancangan Acak Kelompok Faktor Tunggal yaitu penambahan MOL pada jerami sebanyak 3 level perlakuan yaitu :

M 1 = Jerami + MOL Buah

M 2 = Jerami + MOL Bonggol Pisang

M3 = Jerami + MOL Urine

M0 = Jerami (tanpa MOL)

Setiap perlakuan terdiri dari 3 ulangan sehingga diperoleh 12 unit percobaan

\section{Prosedur Penelitian :}

- Sapi lokal sebanyak 12 ekor berumur 2 - 2,5 tahun (dengan berat badan seragam).

- Pada masing-masing perlakuan diberikan konsentrat 1 persen dari berat badan (dedak halus). Pemberian air minum dilakukan secara ad libitum.

- Masa adaptasi terhadap pakan yang akan diuji selama 14 hari. Adaptasi ini bertujuan untuk menghilangkan sisasisa makanan sebelumnya di dalam saluran pencernaan.

- Sebelum dilakukan perlakuan pakan, semua sapi dilakukan penimbangan berat badan. Selanjutnya penimbangan berat badan dilakukan dengan interval14 hari.

\section{Analisis Pendapatan}

Menurut Soekartawi (2002), pendapatan usahatani adalah selisih antara penerimaan dan semua biaya. Pernyataan ini dapat dituliskan sebagai berikut : 
$\pi=\mathrm{TR}-\mathrm{TC}$

Keterangan :

$\pi=$ Pendapatan usahatani

$\mathrm{TR}=$ Total penerimaan

$\mathrm{TC}=$ Total biaya Menurut Soekartawi (2002), penerimaan usahatani adalah perkalian antara produksi yang diperoleh dengan harga jual. Pernyataan ini dapat dituliskan sebagai berikut :

$\mathrm{TR}=\mathrm{Y} . \mathrm{P}_{\mathrm{Y}}$

Keterangan :

$\mathrm{TR}=$ Total penerimaan

$\mathrm{Y}=$ Produksi yang diperoleh

dalam suatu usahatani

$\mathrm{P}_{\mathrm{Y}}=$ Harga penjualan hasil produksi

\section{PELAKSANAAN PENELITIAN}

\section{Waktu dan Tempat Pelaksanaan}

Penelitian dilaksanakan pada bulan Akhir Februari sampai awal Juni 2012 bertempat di Desa Purwodadi Kab. Pasuruan dengan menyewa kandang dan sapi peternak di daerah tersebut.

\section{Tahap Pelaksanaan}

Pelaksanaan penelitian meliputi :

1. Persiapan kandang dan ternak

2. Menimbang dan memeriksakan kesehatanTernak

3. Persiapan alat dan bahan.

4. Pembuatan MOL Buah, Urine, Bonggol pisang selama 2 minggu

5. Pembuatan Pakan (fermentasi jerami dengan MOL) selama 3 minggu

6. Pemberian pakan dengan pola sebagai berikut :

a. Pagi ampas kedelai

b. Siang Hijaun ( rumput gajah )

c. Konsentrat
7. Pengamatan dilakukan dua minggu sekali

8. Pemeliharaan dan perawatan ternak

9. Pembersihan kandang

10. Penimbangan Berat badan akhir dilakukan setelah 3 bulan

\section{Instrumen Pelaksanaan}

Bahan yang digunakan untuk Mol adalah buah-buahan sisa(pasar), bonggol pisang, urine sapi, gula merah, air beras. Bahan fermentasi jerami, urea, tetes. Ternak keseluruhan milik peternak. Kandang sewa dari peternak selama 3 bulan. Alat yang digunakan timbangan ternak sewa, alat pembuat Mol drum, sekrop, pisau penjajah, selang, ember. Alat pembuat konsentrat adalah sekrop ember, gayung, gembor dan terpal.

\section{HASIL DAN PEMBAHASAN}

\section{Penambahan Berat Badan Harian}

\begin{tabular}{ccc}
\multicolumn{2}{c}{ Pertambahan bobot badan } \\
merupakan bagian dari proses
\end{tabular} pertumbuhan, hal ini sesuai dengan pendapat Anggorodi (1985) bahwa pertumbuhan didefinisikan sebagai pertambahan jumlah sel (hyperplasia) dan pertambahan ukuran sel (hipertropi). Pertambahan bobot badan merupakan selisih antara penimbangan bobot badan akhir dengan bobot badan pada penimbangan awal 
Tabel. 1. Data Pertambahan Bobot Badan (kg/ekor/hr)

\begin{tabular}{|l|r|r|r|r|}
\hline \multirow{2}{*}{ Sampel } & \multicolumn{5}{|c|}{$\begin{array}{c}\text { PBBH } \\
\text { (kg/ekor/hr) }\end{array}$} \\
\cline { 2 - 6 } & Kontrol & \multicolumn{1}{|c|}{ Buah } & \multicolumn{1}{l|}{ Bonggol } & Urine \\
\hline 1 & 0.380952 & 0.857143 & 0.698413 & 0.071429 \\
\hline 2 & 0.238095 & 0.904762 & 0.746032 & 0.047619 \\
\hline 3 & 0.47619 & 1.142857 & 0.793651 & 0.02381 \\
\hline Jumlah & 1.095238 & 2.904762 & 2.238095 & 0.142857 \\
\hline Rata-rata & 0.365079 & 0.968254 & 0.746032 & 0.047619 \\
\hline
\end{tabular}

Sumber : Hasil analisis

Berdasarkan hasil penimbangan terhadap pertambahan bobot badan (table 1) diperoleh data pertambahan bobot badan rata-rata dari sapi perlakuan Jerami +MOL Buah terbukti mampu menaikkan berat badan mencapai $60 \%$ hal ini sesuai dengan hasil kajian Badan Pengkajian dan Penerapan Teknologi (2006) bahwa dengan pemberian bahan konsentrat menunjukkan respon yang positif terhadap pertumbuhan ternak sapi. Pada perlakuan Jerami +MOL Bonggol mampu menaikkan berat badan mencapai $40 \%$ sedangkan untuk perlakuan Jerami +MOL Urine sapi menunjukkan penambahan berat badan yang kurang maksimal dikarenakan pada minggu keempat dalam pemberian pakan sapi menunjukkan gejala tidak mau makan sehingga pemberian pakan konsentrat dihentikan.

Rata-rata penambahan bobot badan harian pada table 1. menunjukkan bahwa sapi yang diberi perlakuan dengan pemberian pakan Jerami+MOL buah menunjukkan pertambahan bobot yang paling besar dibandingkan dengan perlakuan lainnya. Hal ini disebabkan adanya perbedaan kemampuan dalam mengkonsumsi bahan kering dan kemampuan beradaptasi terhadap pakan yang tersedia. Siregar (1996) menyatakan bahwa laju pertumbuhan setiap sapi tidak sama, secara umum sapi yang memiliki ukuran tubuh lebih besar akan mempunyai pertumbuhan yang lebih tinggi.

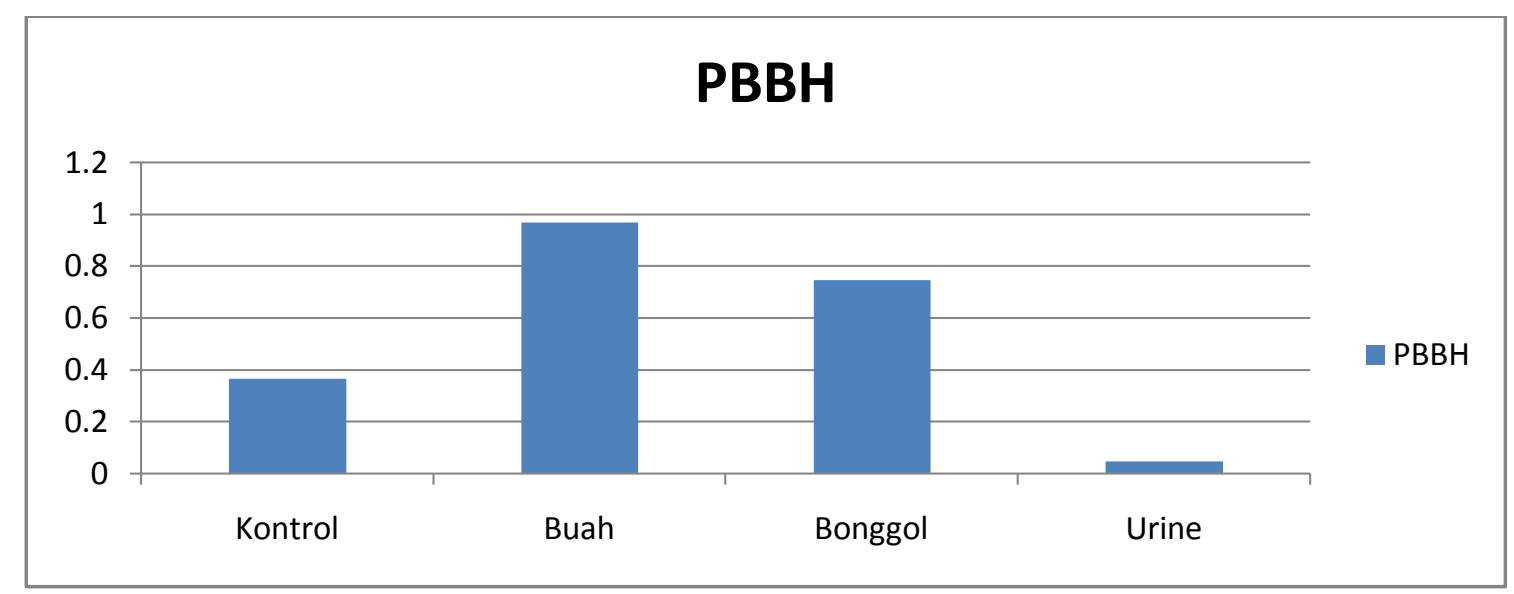

Gambar. 1. Diagram Pertambahan Bobot Badan Harian (PBBH) 
Hasil uji t menunjukkan bahwa pada perlakuan Jerami+Mol Buah berbeda sangat nyata $(\mathrm{P} 0,01)$ terhadap pertambahan bobot badan. Hal ini dikarenakan dengan penambahan Mol Buah akan meningkatkan jumlah bakteri yang ada dalam rumen sehingga meningkatkan daya cerna makanan. Hal ini sesuai dengan pendapat Thomas et al (1961) dalam parakkasi (1999) yang menyatakan bahwa apabila jumlah mikroba sedikit maka tidak dapat mencerna bahan pakan yang masuk secara maksimal sehingga banyak zat makanan tersebut tidak dapat dimetabolisme oleh mikroba rumen untuk dimanfaatkan sebagai sumber energi bagi ternak.

\section{Hasil Uji Kandungan Protein dan Serat Kasar Pada Pakan}

Hasil uji lap terhadap semua perlakuan dapat dilihat pada table 2 . Dari Hasil analisis Lab menunjukkan bahwa pada perlakuan Jerami+MOL Buah menunjukkan kandungan protein yang lebih tinggi dari pada perlakuan yang lain.

Tabel 2. Hasil Uji Lab Pakan (hasil Fermentasi) terhadap Kandungan Protein Kasar dan serat Kasar

\begin{tabular}{|l|l|l|l|l|}
\hline NO & KODE BAHAN & \multicolumn{3}{|l|}{ KANDUNGAN ZAT MAKANAN } \\
\cline { 3 - 5 } & $\begin{array}{c}\text { Bahan Kering } \\
\mathbf{( \% )}\end{array}$ & $\begin{array}{l}\text { Protein Kasar* } \\
\mathbf{( \% )}\end{array}$ & $\begin{array}{c}\text { Serat Kasar* } \\
\mathbf{( \% )}\end{array}$ \\
\hline 1. & $\begin{array}{l}\text { Jerami Padi Fermentasi MOL } \\
\text { BUAH }\end{array}$ & 64,25 & 9,12 & 24,34 \\
\hline 2. & $\begin{array}{l}\text { Jerami Padi Fermentasi MOL } \\
\text { Bonggol Pisang }\end{array}$ & 72,78 & 8,56 & 24,87 \\
\hline 3. & $\begin{array}{l}\text { Jerami Padi Fermentasi MOL } \\
\text { Urine }\end{array}$ & 70,56 & 6,23 & 24,84 \\
\hline 4. & Jerami Padi Kontrol & 57,82 & 3,37 & 68,48 \\
\hline
\end{tabular}

Sumber : Hasil Analisis Laboratorium

Pada perlakuan Jerami Padi +MOL Buah menunjukkan kadar Protein kasar 9,12 \% lebih besar dari perlakuan yang lainnya, sedangkan kandungan serat kasarnya lebih kecil. Hal ini menunjukkan bahwa fermentasi terhadap Jerami oleh MOL Buah bisa menurunkan kandungan serat kasar dan meningkatkan kandungan protein kasar pakan.Hal ini memberikan indikasi bahwa MOL Buah yang ditambahkan mengandung mikroba protelitik yang mengahsilkan enzim protease yang merombak protein menjadi polipeptida yang selanjutnya menjadi peptide sederhana.

\section{Analisis Pendapatan}

Perhitungan analisis usaha ini berlaku asumsi-asumsi antara lain : 
1. Harga beli sapi bakalan dan harga jual sapi mengikuti harga yang berlaku dipasar pada bulan Juni 2012

2. Perhitungan analisis pendapatan ini berlaku untuk satu pereode pembesaran (3 bulan)
3. Penentuan harga konsentrat diasumsikan semua bahan baku yang digunakan adalah beli.

Tabel 3. Hasil Perhitungan Analisis Pendapatan

\begin{tabular}{|c|c|c|c|c|}
\hline Kreteria & Kontrol & Buah & Bonggol & Urine * \\
\hline Biaya tetap & 246,500 & 246,500 & 246,500 & 246,500 \\
\hline Biaya Variabel & Rp 43,687,500 & $38,926,950$ & $38,769,450$ & \\
\hline Total Biaya & Rp 43,934,000 & $39,173,450$ & $39,015,950$ & \\
\hline Penerimaan & Rp 48,200,000 & $48,600,000$ & $46,250,000$ & \\
\hline Keuntungan & $\mathrm{Rp} \quad 4,266,000$ & $9,426,550$ & $7,234,050$ & \\
\hline R/C Ratio & 1.09 & 1.24 & 1.18 & \\
\hline B/C Ratio & 0.09 & 0.24 & 0.18 & \\
\hline
\end{tabular}

*. Pada perlakuan Jerami+Mol Urine tidak dianalisis karena pada pengamatan minggu ke 4 pemberian pakan dihentikan

Dari analisis R/C Ratio diatas dapat diartikan bahwa pada perlakuan Jerami +Mol Buah setiap peningkatan biaya sebesar Rp. 100 akan menghasilkan penerimaan sekitar Rp124. Dari analisis B/C ratio dapat diartikan dari biaya yang dikeluarkan akan diperoleh keuntungan sebesar 0.24 \%. Pada Perlakuan Jerami+Mol Bonggol Pisang R/C Ratio dapat diartikan bahwa setiap peningkatan biaya sebesar Rp. 100 akan menghasilkan penerimaan sekitar Rp124. Dari analisis B/C ratio dapat diartikan dari biaya yang dikeluarkan akan diperoleh keuntungan sebesar 0.24 \%. Dari hasil analisis diatas menunjukkan bahwa pada perlakuan Jerami+Mol Buah maupun Jerami+Mol Bonggol Pisang lebih tinggi dari Kontrol sehingga dapat dikatakan bahwa usaha ternak menggunakan pakan hJerami +fermentasi dengan MOL Buah maupun MOL Bonggol Pisang dapat dikembangkan karena memberikan keuntungan yang relative baik. Keuntungan ini masih dapat ditingkatkan karena bahan-bahan untuk membuat MOL dan jerami melimpah di sekitar daerah penelitian sehingga biaya yang dikeluarkan bisa ditekan.

\section{KESIMPULAN DAN SARAN}

\section{Kesimpulan}

1. Perlakuan Jerami+MOL Buah memberikan Pertambahan Berat Badan Harian PBBH ternak terbaik yaitu sebesar 0,96 (kg/ekor/hr).

2. Hasil Fermentasi terhadap Jerami dengan perlakuan MOL yang menunjukkan hasil terbaik adalah fermentasi dengan penambahan MOL Buah yaitu kandungan protein kasar 9,12 dan kandungan serat kasar 24,34

3. Usaha penggemukan sapi potong dengan pemberian pakan hasil fermentasi Jerami+Mol Buah layak 
diusahakan karena mampu memberikan nilai keuntungan.

\section{Saran}

Perlu dikaji penelitian lebih lanjut tentang pengaruh fermentasi Jerami dengan penambahan MOL untuk kualitas daging sehingga didapat informasi yang lebih mendalam.

\section{DAFTAR PUSTAKA}

Anggorodi, R. 1994. Ilmu Makanan Ternak Umum. PT. Gramedia Pustaka Utama, Jakarta.

Blakely, J. dan D.H. Bade. 1998. Ilmu Peternakan. Gadjah Mada University Press, Yogyakarta. (Diterjemahkan oleh B. Srigandono).

Darmono. 1999. Tatalaksana Usaha Sapi Kereman. Kanisius, Yogyakarta.

Direktorat Pengelolaan Lahan. 2007. Pedoman Teknis Pengembangan Usahatani Padi Sawah Metode System of Rice Intencification (SRI). Direktorat Jenderal Pengelolaan Lahan dan Air Departemen Pertanian. Jakarta.

http://www.google.co.id/searc h. Diakses tanggal 11-112009, pukul 19:01.

Januardani, V. 2008. Cara bikin MOL (Mikroorganisme Lokal).
Blog diposting tanggal 17 September 2008. http://kebunkebunku.blogspot.com/.

Diakses tanggal 05-11-2009, pukul 07:25.

Lubis, D. A. 1992. Ilmu Makanan Ternak. PT Pembangunan, Jakarta.

Santosa, U. 1995. Tata Laksana Pemeliharaan Ternak Sapi. Cetakan I. Penebar Swadaya. Jakarta

Siregar, S. B. 1994. Ransum Ternak Ruminansia. Penebar Swadaya. Jakarta. 2008. Penggemukan Sapi.

Penebar Swadaya. Jakarta.

1998. Beternak Sapi Potong. Penebar Swadaya, Jakarta.

SMPT Harapan Rakyat. 2008. Pemanfaatan Limbah Cair Dan Bahan Organik Dalam Pembiakan Organisme Lokal (Mol) Sebagai Ragi Kompos Dan Pupuk Cair Serta Kebutuhan Usahatani Lainnya.Blog diposting tanggal 9 Juni 2008. http://pertanianorganiklampun g.blogspot.com/. Diakses tanggal 14-12-2009, pukul 13:02.

Tillman, A. D.,S, Reksohadiprodjo, S. Prawirokusumo, H. Hartadi dan S. Lebdosoekojo. 1991. Ilmu Makanan Ternak Dasar. Gadjah Mada University Press, Yogyakarta. 
